\title{
呼吸を用いたマインドフルネス瞑想と ストループ課題との関連の検討
}

\author{
○斎藤翔一郎 ${ }^{1} \cdot$ 越川房子 ${ }^{2}$ \\ ( ${ }^{1}$ 早稲田大学大学院文学研究科・ ${ }^{2}$ 早稲田大学文学学術院 $)$ \\ キーワード：マインドフルネス，注意，ストループ課題
}

Relationship between mindfulness breathing and stroop task.

Shinichiro SAITO ${ }^{1}$, Fusako KOSHIKAWA ${ }^{2}$

$\left({ }^{1}\right.$ Graduate School of Letters, Arts and Sciences, Waseda Univ., ${ }^{2}$ Faculty of Letters, Arts and Sciences, Waseda Univ.)

Key Words: mindfulness, attention, stroop task

\section{目的}

近年, うつや不安への介入に関する概念として, マインド フルネスが注目を集めている。Kabat-Zinn（2003）は，マイン ドフルネスを「意図的に，現在の瞬間に，そして瞬間瞬間に 展開する体験に，判断をせずに注意を払うことで現れる気づ き」と定義している。しかし，マインドフルネスと注意機能 のコントロールを直接的に結びつける研究はまだ数少なく, 結果も一貫していない (Feltman et al., 2009)。Jha et al.(2010) は，判断をせずに注意を払うというマインドフルネスのトレ ーニングが, 注意機能における自発的な入カレベルと反応レ ベル (コンフリクトモニタリング)の機能の選択のプロセスを 変えることを示唆している。また，このコンフリクトモニタ リングを評価する上で，ストループ課題が有用であることが 報告されている(Botvinick,2004)。しかし，マインドフルネス と注意機能に関する研究のうち, 逆ストループ干渉に注目し た研究は類を見ない。そこで本研究では，2 週間のマインド フルネス瞑想が，注意機能にどのような影響を与えるかにつ いて，マインドフルネス尺度及びマインドフルネスの中核で ある脱中心化を測定する脱中心化尺度（日本語版 Experiences Questionnaire:EQの下位尺度)，自己記入式のストル ープ課題, 逆ストループ課題を用いて検討を試みた。ストル 一プ課題とは色に対する言葉の干涉を測定するものであるの に対し, 逆ストループ課題は言葉に対する色の干涉を測定す るものである。

\section{方 法}

実験参加者: 都内の私立大学生・大学院生 36 名 (男性 12 名, 女性 24 名: 平均年齢 21.42 歳, $\mathrm{SD}=1.95$ ）であった。技法群 には 18 名（男性 6 名, 女性 12 名), 統制群には 18 名（男性 6 名, 女性 12 名）を割り当てた。

指標：(1)「新ストループ検査 I」（箱田・渡辺，1990），（2） マインドフルネス尺度（前川，2014），(3)日本語版

Experiences Questionnaire (EQ)の下位尺度である脱中心化 尺度（栗原・長谷川・根建，2010）を指標として用いた。

実験手続き：まず新ストループ検査 Iへの記入を求めた。こ のストループ検査は 4 つの課題から成り立つ自己記入式であ り，逆ストループ効果についても測定することが出来るもの である。その後, マインドフルネス尺度(31 項目), EQ の下 位尺度である脱中心化尺度 $(10$ 項目 $)$ 一の記入を求めた。そし て，技法群には Segal, Williams, and Teasdale(2002)による 「呼吸へのマインドフルネス」を基にした「呼吸を用いたマ インドフルネス瞑想」を 11 分間実施し, 説明した上で 2 週 間の間, CD に録音された瞑想法を毎日実施するように依頼 した。その後，技法群，統制群ともに 2 週間後に再度指標に 記入を求めた。

\begin{abstract}
結 果
1. ストループ干涉率の変化 ストループ干渉率について, 群（技法群・統制群） ×時期（プレ・ポスト）の 2 要因混合 計画による分散分析を行った。その結果, 群の主効果にのみ 有意傾向が見られた $(F(1,34)=4.03, p<.10)$ 。
\end{abstract}

2. 逆ストループ干涉率の変化 プレ時点で群間において $0.1 \%$ 水準で有意な差が認められた $(t(34)=4.10, p<.001)$ ため, 共分散分析を行ったところ, 回帰の平行性を仮定することが できなかった。そのため, 干渉率の変化量（ポストープレ） を用いて, 群間で対応のない $\mathrm{t}$ 検定を行ったところ, 有意な 差は見られなかった（ $t(34)=-2.78$, n.s. $)$ 。

3. マインドフルネス尺度とストループ干涉率, 逆ストル ープ干涉率との相関 マインドフルネス尺度の変化量とス トループ干渉率, 逆ストループ干渉率との変化量の間には, 有意な相関は見られなかった。

4. $E Q$ 脱中心化尺度とストループ干涉率, 逆ストループ干 涉率との相関 $\mathrm{EQ}$ 脱中心化尺度の変化量と逆ストループ干 渉率の変化量の間に, 有意水準 $10 \%$ で有意な弱い負の相関の 傾向 $(r=-.26)$ が見られた。一方，ストループ干渉率との間には 有意な相関は見られなかった。

\section{考 察}

ストループ干涉率についての群の主効果にのみ有意差が見 られ, 時期の主効果及び交互作用は有意では無かった。また, 逆ストループ干渉率についても有意な差は見られなかった。 これらの結果は, 1 日 10 分の 2 週間のマインドフルネス瞑想 実習では注意機能に影響を与えないことを示している。

相関に関しては, EQ 脱中心化尺度と逆ストループ干渉率 との間に有意傾向で弱い負の相関が見られ，ストループ干涉 率との間には有意な相関は認められなかった。ストループ課 題は知覚的な色情報の自動処理を抑制する必要があり, 他方 逆ストループ課題では日常生活において色情報処理より優位 にある文字情報の自動処理を抑制する必要がある。また, 渡 辺・箱田・松本 (2013)は, 逆ストループ課題ではストループ 課題に比べ, ACC（コンフリクトモニタリングを行い, 適切 な資源配分を可能とする領域）の活動が活発になることを指 摘している。これらのことは, 逆ストループ課題がストルー プ課題よりも注意の制御を必要とすることを示している。脱 中心化は注意の制御と関わるものであるため, 脱中心化の増 加と逆ストループ干渉率のみに有意傾向で弱い負の相関が認 められたのかもしれない。そうであるならば，本時実験の結 果は, 逆ストループ課題が脱中心化の程度を測定する客観的 指標の一つとなりうる可能性を示している。今後, さらに検 討を進めていきたい。 